\title{
Ultrastructure of epidermal sensillae in three species of Acoela
}

\begin{abstract}
Ya.I. Zabotin
Kazan (Volga region) Federal University, Kazan, 420008, Russia. E-mail: Yaroslav_Zabotin@rambler.ru

ABSTRACT: The investigation of the cellular organization of Acoela is of great interest for evolutionary morphologists and neurobiologists, since within this group we can observe the various stages of the formation of the nervous system and sensory organs characteristic of higher Bilateria. However, up to date the ultrastructure of epidermal sensory structures was described only for a relatively small number of acoel species. In the present work, four types of monociliary receptors were found in the epidermis of three species of this taxon (Otocelis rubropunctata, Symsagittifera japonica and Amphiscolops sp.). In the epidermis of $O$. rubropunctata there are three types of receptors - sensillae with a thin rootlet (with microvilli and without them), sensillae with a thick rootlet and receptors without a rootlet with stereocilia. In S. japonica the sensillae without a rootlet and with two circles of microvilli were found. Finally, in Amphiscolops sp. the sensillae with a thick rootlet and receptors without a rootlet with stereocilia were described. The distribution of certain types of ciliary receptors in various Acoela species is analyzed and their classification is proposed.

How to cite this article: Zabotin Ya.I. 2019. Ultrastructure of epidermal sensillae in three species of Acoela // Invert. Zool. Vol.16. No.1. P.71-77. doi: 10.15298/invertzool.16.1.08
\end{abstract}

KEY WORDS: Acoela, sensillae, ciliary receptors, sensory organs, morphology, ultrastructure.

\section{Ультраструктура эпидермальных сенсилл трех видов бескишечных турбеллярий (Acoela)}

\section{Я.И. Заботин}

Казанский (Приволжский) федеральный университет, Казань, 420008, Россия. E-mail: Yaroslav_Zabotin@rambler.ru

РЕЗЮМЕ: Изучение клеточной организации бескишечных турбеллярий (Acoela) представляет большой интерес для морфологов-эволюционистов и нейробиологов, поскольку именно в пределах этой группы можно наблюдать различные этапы формирования нервной системы и органов чувств, характерных для высших Bilateria. Тем не менее, на сегодняшний день ультраструктура сенсорных образований описана лишь для небольшого числа видов Acoela. В данной работе у трех видов этого таксона (Otocelis rubropunctata, Symsagittifera japonica и Amphiscolops sp.) в покровах было обнаружено четыре типа одноресничных рецепторов. В эпидермисе $O$. rubropunctata встречается три типа сенсилл - с тонким корешком (с микровиллями и без них), с толстым корешком, а также сенсиллы без корешка со стереоцилиями. У 
S. japonica были обнаружены сенсиллы без корешка и с двумя кругами микровиллей. Наконец, у Amphiscolops sp. отмечены сенсиллы с толстым корешком и рецепторы без корешка со стереоцилиями. Анализируется распространение определенных типов ресничных рецепторов у различных видов Acoela и предлагается их классификация.

Как цитировать эту статью: Zabotin Ya.I. 2019. Ultrastructure of epidermal sensillae in three species of Acoela // Invert. Zool. Vol.16. No.1. P.71-77. doi: 10.15298/invertzool. 16.1 .08

КЛЮЧЕВЫЕ СЛОВА: Бескишечные турбеллярии (Acoela), сенсиллы, ресничные рецепторы, органы чувств, морфология, ультраструктура.

\section{Introduction}

The investigation of the cellular organization of Acoela (Acoelomorpha) is of great interest for evolutionary morphologists and neurobiologists, since within this group we can observe the various stages of the formation of the nervous system and sensory organs characteristic of higher Bilateria. The primitive features of nervous system of Acoela are combined with the high diversity of epidermal ciliary receptors, most likely responsible for tactile and chemosensory functions. As a rule, they are scattered over the whole body, forming concentrations on the anterior end around the glandular frontal organ (Smith, Tyler, 1985, 1986) and on the ventral side around the mouth opening and pharynx (Todt, Tyler, 2006, 2007).

The most relevant and detailed reviews on ciliary receptors of Acoela were provided by Todt \& Tyler (2007) and Haszprunar (2016). E.g., Raikova (1989) described four types of ciliary receptors in four species of Acoela: monociliary sensillae with a thin rootlet, monociliary sensillae with a thick rootlet, monociliary collared sensillae and multiciliary sensillae. The receptors of another four species of Acoela, studied by Todt \& Tyler (2007) were found to bear the single cilium. Among them there are sensillae with a thin rootlet, sensillae with two rootlets, sensillae with a thick rootlet (all of them are non-collared), collared sensillae with a rootlet composed of the strand-like elements and collared sensillae without a rootlet. Howev- er, up to date the ultrastructure of epidermal sensory structures was described only for a relatively small number of acoel species (e.g., Bedini et al., 1973; Popova, Mamkaev, 1987; Raikova, 1989; Pfistermüller, Tyler, 2002; Todt, Tyler, 2007). Thus, the aim of the present work was to study the ultrastructure of the epidermal sensillae of three species of this taxon, previously never investigated with a transmission electron microscope (TEM).

\section{Material and methods}

The representatives of three species of Acoela - Otocelis rubropunctata (Schmidt, 1852) (Isodiametridae), Symsagittiferajaponica (Kato, 1951) (formerly known as Convoluta japonica, Convolutidae) and Amphiscolops sp. (described by Minegishi (1965) without a specific name, Convolutidae) - were collected on sandy littoral and algae of Mukaishima Island (Hiroshima Prefecture, Japan). The entire animals were fixed in $1 \%$ glutaraldehyde on $0.1 \mathrm{M}$ phosphate buffer. The samples were prepared for the TEM including the post-fixation in 1\% osmium tetroxide on $0.1 \mathrm{M}$ phosphate buffer, dehydration from $30 \%$ to absolute alcohol and acetone, embedding in Epon epoxy resin. Ultrathin sections were made using ultramicrotome ReichertJung, contrasted with uranyl acetate and lead citrate and investigated using TEM JEM 100 CX in the Department of Zoology and General Biology of Kazan (Volga Region) Federal University (Kazan, Russia). 


\section{Results}

In the epidermis of three species of Acoela four types of monociliary receptors were found. They differ in the presence of rootlets and their shape, the presence of microvilli, stereocilia and subbasal body. As in the epidermal cells, microtubules in the axonemes of cilia are arranged according to the classical formula $9+2$. Cell contacts of all types of sensillae with neighboring cells of the epidermis have a similar appearance - the area of membrane contact is marked by clearly visible desmosomes.

\section{Otocelis rubropunctata}

1.1. Monociliary sensillae with a thin rootlet (Fig. 1A). The ciliary receptor is $0.5 \mu \mathrm{m}$ wide in the terminal part and $1 \mu \mathrm{m}$ in the basal part. Sensilla bears a single cilium. The terminal part of the sensilla with a basal body of cilium rises up to $1 \mu \mathrm{m}$ above the surface of epidermal cells. Sometimes rather short (about $0.5 \mu \mathrm{m}$ in length) microvilli originating from the terminal surface of sensilla are present. The rootlet is $0.25 \mu \mathrm{m}$ wide and has transverse striation, especially well-distinguished near the kinetosome of the cilium. In the basal part of the rootlet an elongated electron-dense body, possibly performing an additional supportive function, is located. The cytoplasm is poor in organelles; very small electron-lucent vesicles are scattered in the basal part of the sensilla.

1.2. Monociliary sensillae with a thick rootlet. The receptor reaches a width of $0.75 \mu \mathrm{m}$. Sensilla bears one cilium, no microvilli were detected. The rootlet of the cilium is very thick (up to $0.5 \mu \mathrm{m}$ wide) and transversely striated. Small electron-lucent vesicles with a dense core are located in the cytoplasm.

1.3. Monociliary sensillae with stereocilia (Fig.1B, C). Ciliary receptor of this type is $1 \mu \mathrm{m}$ wide in the terminal part; deeper it narrows to $0.5 \mu \mathrm{m}$. Sensilla has a single central cilium surrounded by collar of stereocilia having an incline to the center. Ciliary rootlet is absent and replaced by large electron-dense subbasal body $(0.75 \mu \mathrm{m}$ in diameter) located in the cytoplasm. It possesses a form of a "swallow's nest" with a recess on the upper surface. The cytoplasm is electron-dense; numerous electron-lucent vesicles with a dense core are scattered in the terminal part.

\section{Symsagittifera japonica}

2.1. Monociliary sensillae without a rootlet (Fig. 1D). The ciliary receptor has a width of 0.5 $\mu \mathrm{m}$ in the terminal part; deeper it expands to 1 $\mu \mathrm{m}$. Sensilla has a single cilium surrounded by two circles of microvilli. The inner microvilli are longer than the outer ones and contain small electron-dense inclusions in the base. The rootlet is absent; the elongated electron-dense subbasal body $0.5 \mu \mathrm{m}$ wide is located under the kinetosome.

\section{Amphiscolops sp.}

3.1. Monociliary sensillae with a thick rootlet (Fig. 1E). Sensillae of this type are similar in structure with those of $O$. rubropunctata. In the Amphiscolops sp. they often form associations with monociliary sensillae with stereocilia (see below).

3.2. Monociliary sensillae with stereocilia (Fig. 1E). These goblet-shaped sensillae have a width of $1 \mu \mathrm{m}$ in the terminal part, and then expand to $1.5 \mu \mathrm{m}$ in the middle part and deeper again narrow to $0.75 \mu \mathrm{m}$. Sensilla bears a single cilium without a rootlet and a crown of long straight stereocilia. The actin microfilaments of stereocilia continue deeply to cytoplasm. Slightly below the surface there is a very large electrondense cylindrical subbasal body, up to $0.75 \mu \mathrm{m}$ in diameter. Its upper and lower surfaces have recesses. The cytoplasm of the receptor is electron-lucent; it contains mitochondria and multiple inclusions, including the small transparent vesicles with a dense core, larger vesicles filled with smaller ones, as well as large rounded vacuoles.

\section{Discussion}

According to the original and literary data, the classification of epidermal ciliary receptors of Acoela and their distribution in the certain species can be presented as follows. 

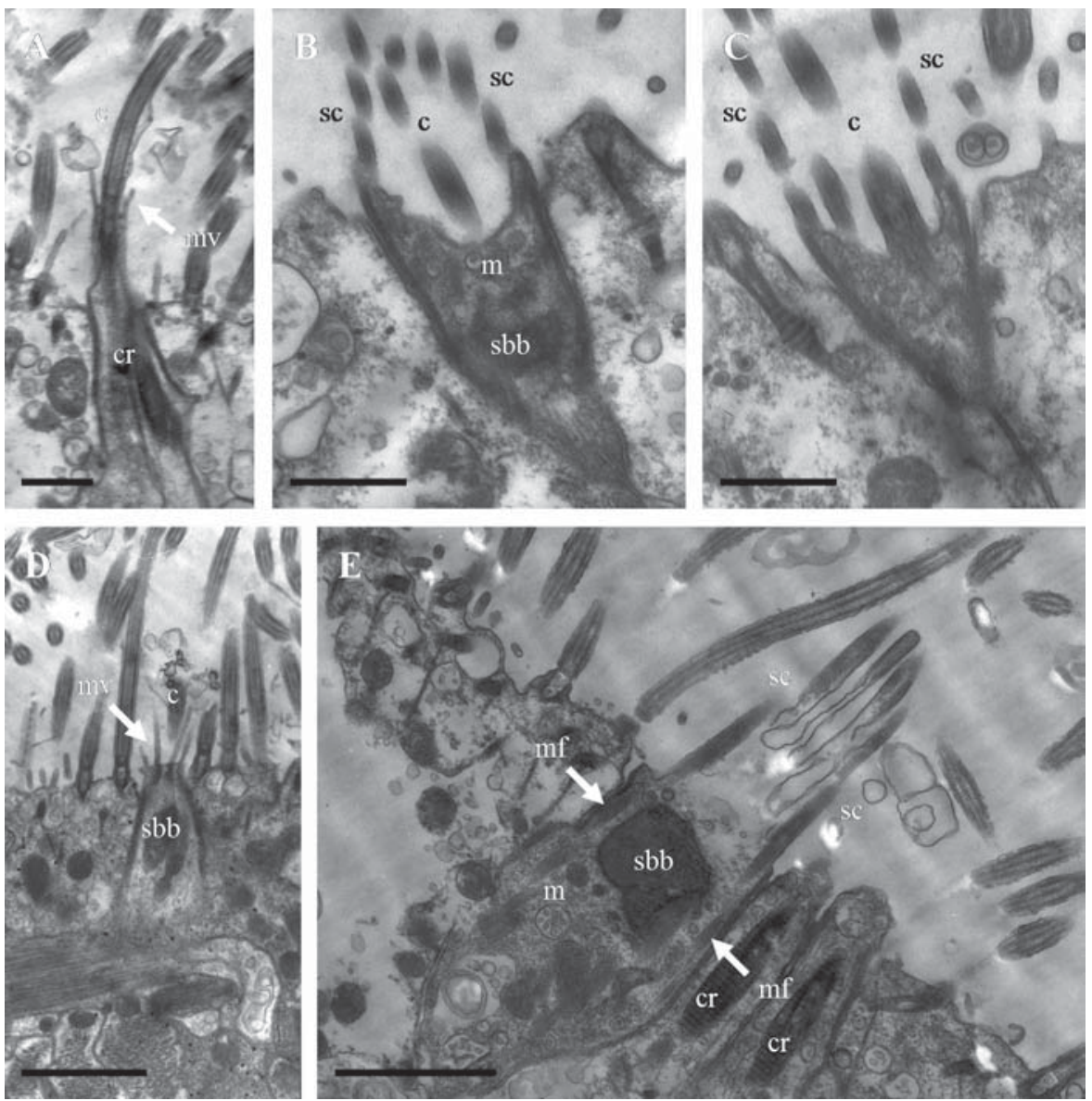

Fig. 1. The ultrastructure of epidermal monociliary sensillae of Acoela. A - sensilla with a thin rootlet and microvilli of Otocelis rubropunctata; B, C - sensillae with stereocilia of O. rubropunctata; D - sensilla without a rootlet of Symsagittifera japonica; E - sensilla with stereocilia and two sensillae with a thick rootlet of Amphiscolops sp.

Abbreviations: $\mathrm{c}-$ cilia; $\mathrm{cr}-$ ciliary rootlet; $\mathrm{m}-$ mitochondria; $\mathrm{mf}$ - microfilaments; $\mathrm{mv}-$ microvilli; $\mathrm{sbb}-$ subbasal body; sc — stereocilia. Scale bar: $1 \mu \mathrm{m}$.

Рис. 1. Ультраструктура эпидермальных одноресничных сенсилл Acoela. A - сенсилла с тонким корешком и микровиллями Otocelis rubropunctata; $\mathrm{B}, \mathrm{C}$ - сенсиллы со стереоцилиями O. rubropunctata; D - сенсилла без корешка Symsagittifera japonica; E - сенсилла со стереоцилиями и две сенсиллы с толстым корешком Amphiscolops sp.

Обозначения: c - реснички; $\mathrm{cr}$ - корешок реснички; $\mathrm{m}$ - митохондрия; $\mathrm{mf}$ - микрофиламенты; $\mathrm{mv}-$ микровилли; sbb - подбазальное тело; sc - стереоцилии. Масштаб: $1 \mu \mathrm{m}$.

\section{Monociliary sensillae with a thin rootlet} (Fig. 2A) are characterized by long thin transversely-striated rootlet and sometimes by presence of microvilli. They are widespread among the different families of Acoela. Particularly, sensillae of this type are noted in Convoluta convoluta, Oxyposthia praedator (Popova,
Mamkaev, 1987), Symsagittifera psammophila, Mecynostomum sp. (Bedini et al., 1973), Haploposthia opisthorchis, Actinoposthia beklemischevi, Anaperus biaculeatus, Aphanostoma virescens (Raikova, 1989), Hofstenia miamia and Proporus bermudensis (Todt, Tyler, 2007). Thus, they are found in representatives 
of various acoel families - both primitive (Hofsteniidae, Proporidae, Isodiametridae etc.) and derived ones (Convolutidae). In some cases these sensillae were found to bear the microvilli, e.g. in Hofstenia miamia (Todt, Tyler, 2007). These receptors in both variants (with and without microvilli) are found in Otocelis rubropunctata in the present study.

2. Monociliary sensillae with a thick rootlet (Fig. 2B) are diagnosed by rather short, wide and transversely-striated rootlet. These sensillae are also often found in Acoela, but differ in the presence or absence of microvilli in the certain species. Particularly, sensillae in $O x$. praedator (Popova, Mamkaev, 1987) and four above-mentioned species studied by Raikova (1989) possess microvilli, while in case of $P$. bermudensis they are absent (Todt, Tyler, 2007). In addition, in C. convoluta and Conaperta thela both variants were described (Popova, Mamkaev, 1987; Todt, Tyler, 2007). The sensillae observed in the present work in O. rubropunctata and Amphiscolops sp. are lacking microvilli.

3. Monociliary sensillae without a rootlet (Fig. 2C) possess a single cilium, surrounded by two circles of microvilli. The rootlet is lacking; instead of it the large electron-dense subbasal body is present. These sensillae are described by various authors in multiple acoel species (Bedini et al., 1973; Popova, Mamkaev, 1987; Raikova, 1989; Pfistermüller, Tyler, 2002; Todt, Tyler, 2007), as well as in $S$. japonica described in the present study.

Because of the presence of two circles of microvilli the sensillae of $S$. japonica resemble the similar receptors of $A$. beklemischevi, An. biaculeatus, Aph. virescens (Raikova, 1989) and Isodiametra pulchra (Pfistermüller, Tyler, 2002), but differ from $H$. opisthorchis, where the inner circle of microvilli is absent (Raikova, 1989). According to Raikova (1989), the large number of peripheral microvilli and the absence of central ones in collared rootlet-less receptors of $H$. opisthorchis are considered as primitive characters. At the same time, the collared sensillae of $S$. japonica are characterized by their own distinctive feature - the unusual, elongated shape of the subbasal body.

\section{Monociliary sensillae with stereocilia} (Fig. 2D) are also characterized by the absence of ciliary rootlet and the presence of subbasal body. The central cilium is surrounded by the collar of stereocilia, also usually identified in literature as "microvilli". This type of sensillae was found in C. convoluta ("rootlet-less sensillae", Popova, Mamkaev, 1987), P. bermudensis, Conaperta thela (Todt, Tyler, 2007) and other four acoel species ("collared receptors", Raikova, 1989).

These sensillae generally resemble the receptors of the previous type with some differences. The stereocilia of $O$. rubropunctata and Amphiscolops sp. differ from the short and thin microvilli of $S$. japonica by the larger diameter and filamentous internal structure, so, to our opinion, these two types of sensillae should be distinguished. Particularly, Raikova (1989) describe the microfilaments of stereocilia (called "microvilli" in the article) continuing deeply into the cytoplasm of the sensory cell. Similar internal structure of stereocilia is observed here for Amphiscolops sp.

Several receptor types not found during the present study but described by the previous authors should also be added to the abovementioned classification.

5. Monociliary sensillae with two rootlets were found in Myopea sp., Solenofilomorpha sp. (Todt, Tyler, 2006) and Hofstenia miamia (Todt, Tyler, 2007). These receptors are lacking microvilli and possess the main rootlet and the smaller posterior one. Unlike the other receptor types, scattered over the whole body, the position of sensillae with two rootlets in Hofstenia miamia is restricted to the mouth and pharynx regions (Todt, Tyler, 2007).

6. Monociliary sensillae with a balloonshaped cilium were observed on the anterior end of the body of Diopisthoporus gymnopharyngeus (Smith, Tyler, 1985, 1986), although, according to authors, they are not unique for this body area. This probably rare type of ciliary receptor is characterized by very short spherical cilium with a single striated rootlet.

7. Monociliary sensillae with a thin rootlet and myofibrils are divided into two halves - 

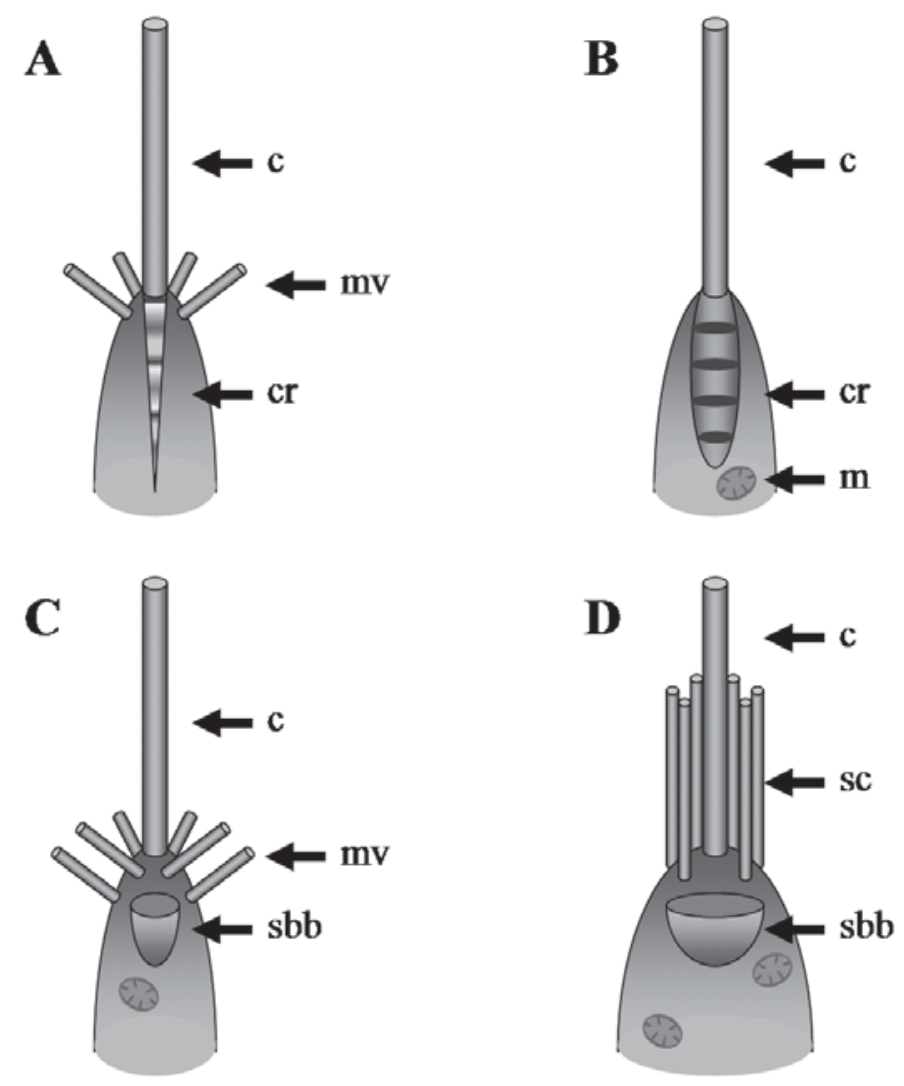

Fig. 2. Schematic reconstructions of apical parts of epidermal monocliliary sensillae of Acoela. A - sensilla with a thin rootlet and microvilli; B - sensilla with a thick rootlet; $\mathrm{C}$ - sensilla without a rootlet; D sensilla with stereocilia.

Abbreviations: $\mathrm{c}$ - cilia; $\mathrm{cr}$ - ciliary rootlet; $\mathrm{m}-$ mitochondria; $\mathrm{mv}$ - microvilli; sbb - subbasal body; $\mathrm{sc}-$ stereocilia.

Рис. 2. Схематическая реконструкция апикальных частей эпидермальных одноресничных сенсилл Acoela. A - сенсилла с тонким корешком и микровиллями; В - сенсилла с толстым корешком; C сенсилла без корешка; D - сенсилла со стереоцилиями.

Обозначения: c — реснички; $\mathrm{cr}$ - корешок реснички; $\mathrm{m}$ — митохондрия; $\mathrm{mv}$ — микровилли; sbb — подбазальное тело; sc - стереоцилии.

the terminal sensitive part and the basal contractile one. The terminal part bears the single cilium with a thin rootlet; the basal one contains the bundle of myofibrils. This unusual type of sensilla was found in C. convoluta and probably represents the sensory-muscular cell — the structure of interest for the origin and connections between the nervous, sensory and muscular systems of bilaterians (Zabotin, Golubev, 2017).

8. Multiciliary sensillae appear to occur much less frequently in the Acoela than mono- ciliary ones. Neither Bedini et al. (1973), nor Todt \& Tyler (2007) mention these receptors in the species they studied. Smith \& Tyler (1986) mention the sensillae bearing from one to four cilia in the anterior end of Paratomella sp.; particularly, the biciliary receptor is seen on the illustration. Popova and Mamkaev (1987) described "biciliary sensillae with coiled cilia" in C. convoluta and Ox. praedator. Multiciliary sensillae of four species of Acoela studied by Raikova (1989) were found to be associated 
with secretory cells and therefore form sensoryglandular organs. She also refers the "biciliary sensillae" described by previous authors to the same type.

As a conclusion, some receptor types are abundant among the various families of Acoela (e.g., monociliary sensillae with a thin rootlet, with a thick one and without a rootlet); while the remaining types seem to be specific for the certain taxa. E.g., the sensillae with two rootlets and sensillae with a balloon-shaped cilium up to date were found only in rather primitive acoel families Diopisthoporidae, Hofsteniidae and Solenofilomorphidae, according to the modern phylogenetic analysis, occupying the basal position within this taxon (Jondelius et al., 2011). On the other hand, their affinities can be explained by the functionary restriction of these receptors to the specific body regions, but not by the phylogenetic position. The present study confirms the higher diversity of sensory organs in Acoela than previously expected, although the function of each certain type of sensillae still remains unclear.

\section{References}

Bedini C., Ferrero E., Lanfranchi A. 1973. The ultrastructure of ciliary sensory cells in two Turbellaria Acoela // Tissue and Cell. Vol.5. No.3. P.359-372.

Haszprunar G. 2016. Review of data for a morphological look on Xenacoelomorpha (Bilateria incertae sedis) // Organisms Diversity and Evolution. Vol.16. P.363389.
Jondelius U., Wallberg A., Hooge M., Raikova O.I. 2011. How the worm got its pharynx: phylogeny, classification and Bayesian assessment of character evolution in Acoela // Systematic Biology. Vol.60. No.6. P.845871.

Minegishi H. 1965. [Acoela-Turbellaria] // New Illustrated Encyclopedia of the Fauna of Japan. Part I. Tokyo: Hokuryu-kan Publ. P.311-312 [in Japanese].

Pfistermüller R., Tyler S. 2002. Correlation of fluorescence and electron microscopy of F-actin-containing sensory cells in the epidermis of Convoluta pulchra (Platyhelminthes: Acoela) // Acta Zoologica. Vol.83. P.15-24.

Popova N.V., Mamkaev Yu.V. 1987. [On types of sensillae in the acoel turbellarians] // Trudy Zoologicheskogo Instituta AN SSSR. Vol.167. P.85-89 [in Russian with English summary].

Raikova O.I. 1989. [Ultrastructure of the nervous system and sensory receptors of acoel turbellarians] // Trudy Zoologicheskogo Instituta AN SSSR. Vol.195. P.3646 [in Russian with English summary].

Smith J.P.S., Tyler S. 1985. Fine structure and evolutionary implications of the frontal organ in Turbellaria Acoela. 1. Diopisthoporus gymnopharyngeus sp. n. // Zoologica Scripta. Vol.14. P.91-102.

Smith J.P.S., Tyler S. 1986. Frontal organs in the Acoelomorpha (Turbellaria): ultrastructure and phylogenetic significance // Hydrobiologia. Vol.132. P.71-78.

Todt C., Tyler S. 2006. Morphology and ultrastructure of the pharynx in Solenofilomorphidae (Acoela) // Journal of Morphology. Vol.267. P.759-883.

Todt C., Tyler S. 2007. Ciliary receptors associated with the mouth and pharynx of Acoela (Acoelomorpha): a comparative ultrastructural study // Acta Zoologica. Vol.8. P.41-58.

Zabotin Ya.I., Golubev A.I. 2017. [On the origin of the nervous system based on studying sensillae in acoel turbellarians (Acoela)] // Uchenye Zapiski Kazanskogo Universiteta. Seriya Estestvennye Nauki. Vol.159. No.3. P.421-432 [in Russian with English summary].

Responsible editor E.N. Temereva 